\title{
Soil Microbial Activities Influenced By Oil Palm Cultivation In A Coastal Plain Sands Area Of Akwa Ibom State, Nigeria
}

\author{
Chukwu, E. D. ${ }^{1}$, Udoh, B. T. ${ }^{2}$, Okoli, N. H. ${ }^{1}$ Nnabuihe, E. C. ${ }^{3}$ \\ 1. Department of Soil Science and Technology, Federal University of Technology P.M. B. 1526 Owerri, Imo State, Nigeria. \\ 2. Department of Soil Science and Land Resources Management, University of Uyo, Uyo, P.M.B 1017 Akwa Ibom State, Nigeria \\ 3. Nnamdi Azikiwe University,P.M.B. 5025 Awka, Anambra State, Nigeria \\ DOI: $10.29322 /$ IJSRP.10.05.2020.p10143 \\ http://dx.doi.org/10.29322/IJSRP.10.05.2020.p10143
}

\begin{abstract}
The study was carried out to evaluate the activities of soil microorganism influenced by oil palm cultivation in a coastal plain sands area of Akwa Ibom State Nigeria. Four locations were identified, namely: oil palm plantations or block of 57 years (B57), 39 years (B-39), 17 years (B-17) and a no oil palm block (B$0)$. Three representative profile pits were sunk in each location and soil samples were collected for laboratory analyses in the wet and dry seasons. The result showed that oil palm slightly increased the bacterial density as well as the respiration rate of the soil of the study area. The trend was as follows: B-39> B-17> B-0> B-57. Bacterial density was significantly $(\mathrm{P}>0.05)$ higher in the wet season than in the dry season in three of the locations. Microbial activities increased with the age of oil palm up to 39 years, then decreases as the palm ages.
\end{abstract}

Index Terms- Bacterial density, Microbial activities, Oil palm, Respiratory rate.

\section{INTRODUCTION}

$\mathrm{O}_{\mathrm{t}}^{\mathrm{i}}$ il palm (Elaeis guineensis jacq) is a high economic important tree crop, because of its high-yielding source of edible and technical oils. Oil palm is an agricultural product which supplies around $36 \%$ of the world's vegetable oil (USDA, 2014), of which a small percentage is used for biodiesel.

The most important constraint to oil palm production is soil fertility. It was estimated that more than 95 percent of oil palms grown in Southeast Asia are on acid, low fertility and highly weathered soils (Pauli et al., 2014). Soil physical properties such as depth, texture and structure are important factors in determining suitability for large scale oil palm production. These are based on the required clay loam texture that imposes friable consistency, capacity to permit extensive root development, firm anchorage, and capacity to store sufficient water and plant nutrients (Foster $e t$ al., 2011; Sayer et al., 2012). Majority of oil palm roots are found within the first $60 \mathrm{~cm}$ of the soil. Therefore, these requisite soil conditions and nutrient status that favour growth and development is indispensable within the $0-60 \mathrm{~cm}$ depth, yet the importance of firm anchorage creates the need for deeper soils (greater than 90 $\mathrm{cm}$ ) (Pauli et al., 2014). However, there is almost no research information on the impact of the plantation on some of the biological indicators of soil quality such as micro and macro organisms, their activities or by-products.

Respiration rate can be used to detect microbial activity, specifically microbial decomposition of organic matter in the soil (USDA- NRCS, 1996). Oil palm plantation influences feeding activity of soil fauna is related to soil chemical parameters (Abu Bakar et al., 2010). The aim of this study was to evaluate the activities of soil microorganism as Influenced by oil palm cultivation in a coastal plain sands area of Akwa Ibom State, Nigeria.

\section{MATERIALS AND METHODS}

\subsection{Description of the Study Location}

The study site was in Nigerian Institute for Oil Palm Research (NIFOR) substation Ibesit Ekoi in Oruk Anam Local Government Area of Akwa Ibom State Nigeria. Oruk Anam Local Government Area is bounded within latitudes $4^{\circ} 45^{\prime}$ and $5^{\circ} 00^{\prime} \mathrm{N}$ and longitudes $7^{\circ} 30^{\prime}$ and $7^{\circ} 45^{\prime}$ F. Oruk Anam Local Government Area falls within the area covered by coastal plain sands. Soils on coastal plain sands are normally deep, dominantly sandy with low clay, organic matter content and $\mathrm{pH}$. The climate of the area is the humid tropical climate, characterized by heavy rainfall with mean annual rainfall of about $4000 \mathrm{~mm}$ and a mean annual temperature of $27^{\circ} \mathrm{C}$. Rainy season is from April to November and is characterized by high relative humidity and high cloud covers resulting in low incipient solar radiation. The soils of the area are formed from the quaternary sedimentary deposits. The relief of the area is low-lying coastal topography and has the major topographic unit namely; Alluvial plains (mangrove and flood plains) beach ridge sands and rolling sandy plains (Udoh, 2003). The vegetation of the area is the forest vegetation in the tropical forest zone.

\subsection{Field Studies}

Four locations were identified in the Nigerian Institute for Oil Palm Research (NIFOR) sub-station located at Ibesit Ekoi in Oruk Anam Local Government Area of Akwa Ibom State Nigeria, which were oil palm blocks of varying ages: (i) 1960-2017 (B-57); (ii) 1979 -2017 (B-39); (iii) 2000- 2017 (B-17) and a no oil palm block (B-0), which served as the control. The NIFOR plantation covers an area of 286 hectares. The area covered by each block was 5.8 ha (B-0), 5.2 ha (B-17), 5.0 ha (B-39) and 5.75 ha (B-57). 
The 57 years old palm plantation was selected because it is the oldest palm in the NIFOR plantation as at 2017 and has almost far past the expected age of replacement of oil palm stand (35 years) as reported by Ukuteno et al. (2012). The oil palm block of 39 years was selected because it was the available palm block which was a little bit past the suggested age for replacement of oil palm (35 years). The 17 year old palm was selected because it fell within the age of optimum yield of 15-20 years (Verheye, 2010) while the no-oil palm block (B-0) which was used as the control was a virgin forest.

Free survey was used to locate representative positions for profile pits. The profile pits were sunk along the middle slope in each of the four blocks to maintain uniformity in topography. Three profile pits were sunk in each of the four blocks (B-57, B39 , B-17 and B-0) which summed up to 12 profile pits used for the study. Soil samples were collected according to the horizon designation as observed in the profile pits. Soil samples were collected for two seasons; dry season sampling in February 2017 and wet season sampling in July 2017, to assess the effects of seasonal variation on the microbial activities. A total of 144 samples were collected for the two seasons (72 samples each for the two seasons). The soil samples were air dried, sieved with $2 \mathrm{~mm}$ mesh sieve and subjected to laboratory analysis.

\subsection{Laboratory analysis}

i. Microbial Count (Bacteria Isolation Density)

Bacteria density was determined using Nester et al., (2006) method. Soil samples were passed through decimal dilution to the sixth factor. I milliliter were plated out on nutrient agar.

Growth inhibitors for fungi were added to growth culture medium. Prepared plates were incubated at $37^{\circ} \mathrm{C}$. After incubation, visible growth colonies were counted. ii. Microbial Respiration

Microbial respiration rate (MR) was measured using the Draeger- Tube method as described by Doran et al. (1996)). Soil samples (moistened to $30 \%$ of field capacity) were transferred to a bottle with a glass test tube containing an alkali solution (1N $\mathrm{NaOH}$ ); the bottle was closed and maintained at $25^{\circ} \mathrm{C}$ for seven days. The trapped $\mathrm{CO}_{2}$ was calculated as a function of soil respiration by titration of the contents of the test tube with $\mathrm{HCl}$ after $\mathrm{BaCl}_{2}$ pretreatment.

\subsection{Statistical analysis}

Data obtained were subjected to statistical analysis, using the statistical software package of SPSS 18.0 (SPSS, 2011) to obtain the following: Descriptive statistics to determine the mean, minimum and maximum values. Analysis of Variance (ANOVA) to compare the differences in soil characteristics among the different locations. Means were separated using LSD and T- test was used to compare the results of the soil properties analyzed for the two seasons.

\section{RESULTS AND DISCUSSIONS}

\subsection{No Oil Palm Block (B-O)}

The result of soil analysis for the biological properties of the no oil palm block (B-0) (control) is presented in Table 1 Bacterial density was moderate and ranged from $6.00-7.20 \mathrm{cfu} / \mathrm{g} \mathrm{x}$ $10^{5}$ in profile $1 ; 6.70-7.20 \mathrm{cfu} / \mathrm{g} \times 10^{5}$ in profile 2 and $5.60-6.70$ $\mathrm{cfu} / \mathrm{g} \times 10^{5}$ in profile 3 . The bacterial density reduced down the three profiles with the least density observed in profile 3 . Respiratory rate $(\mathrm{RR})$ ranged from $0.79-3.21$ in profile $1 ; 0.88$ 4.28 in profile 2 and $1.81-4.06$ in profile 3.

Table 1: Bacterial density and respiratory rate of soil of the no-oil palm block (B-O) (Control)

\begin{tabular}{|c|c|c|c|}
\hline Horizon Depth & Horizon Designation & Bac.D (cfu/g x 10 $\left.0^{5}\right)$ & RR \\
\hline \multicolumn{4}{|l|}{ Profile 1} \\
\hline $0-30$ & Ap & 7.20 & 3.21 \\
\hline $30-60$ & $\mathrm{Bt}_{1}$ & 7.20 & 3.09 \\
\hline $60-97$ & $\mathrm{Bt}_{2}$ & 6.50 & 2.78 \\
\hline $97-126$ & $\mathrm{Bt}_{3}$ & 6.00 & 2.38 \\
\hline $126-154$ & $\mathrm{Bt}_{4}$ & 6.00 & 1.75 \\
\hline $154-200$ & $\mathrm{C}$ & 6.10 & 0.79 \\
\hline Mean & & 6.50 & 5.52 \\
\hline Maximum value & & 7.20 & 3.21 \\
\hline Minimum value & & 6.00 & 0.79 \\
\hline \multicolumn{4}{|l|}{ Profile 2} \\
\hline $0-30$ & Ap & 7.10 & 4.28 \\
\hline $30-62$ & $\mathrm{Bt}_{1}$ & 7.20 & 3.35 \\
\hline $62-94$ & $\mathrm{Bt}_{2}$ & 7.10 & 2.84 \\
\hline $94-126$ & $\mathrm{Bt}_{3}$ & 7.00 & 2.57 \\
\hline $125-160$ & $\mathrm{C}_{1}$ & 6.80 & 1.82 \\
\hline $160-200$ & $\mathrm{C}_{2}$ & 6.70 & 0.88 \\
\hline Mean & & 6.98 & 2.62 \\
\hline Maximum value & & 7.20 & 4.28 \\
\hline Minimum value & & 6.70 & 0.88 \\
\hline \multicolumn{4}{|l|}{ Profile 3} \\
\hline $0-29$ & Ap & 6.70 & 4.06 \\
\hline
\end{tabular}

This publication is licensed under Creative Commons Attribution CC BY. 


\begin{tabular}{llll}
$29-62$ & $\mathrm{Bt}_{1}$ & 6.00 & 3.40 \\
$62-92$ & $\mathrm{Bt}_{2}$ & 5.60 & 3.23 \\
$92-122$ & $\mathrm{Bt}_{3}$ & 6.00 & 2.92 \\
$122-158$ & $\mathrm{C}_{1}$ & 5.70 & 2.28 \\
$158-200$ & $\mathrm{C}_{2}$ & 5.20 & 1.81 \\
Mean & & 5.87 & 2.95 \\
Maximum value & & 6.70 & 4.06 \\
Minimum value & & 5.20 & 1.81 \\
\hline
\end{tabular}

Source: Field data (2017) Bac. $\mathrm{D}=$ bacterial density, $\mathrm{RR}=$ respiratory rate

\subsection{Seventeen Years Old Oil Palm Block (B-17)}

The result of analysis of soil biological properties of B -17 is presented in Table 2. Bacterial density was moderate and ranged from $4.30-5.70$ cfulg x $10^{5}$ in profile $1 ; 6.30-8.10 \mathrm{cfu} / \mathrm{g} \times 10^{5}$ in profile 2 and $5.80-7.60 \mathrm{cfu} / \mathrm{g} \times 10^{5}$ in profile 3 . The bacterial density reduced down the three profiles with the least density in profile 1. Respiratory rate (RR) ranged from 1.07-3.16 in profile 1 ; 0.99-3.06 in profile 2 and 1.42-3.30 in profile 3.

\subsection{Thirty Nine Years Old Oil Palm Block (B-39)}

The result of analysis of soil biological properties of B -39 is presented in Table 3 .

Bacterial density was moderate and ranged from 3.00-6.50 cfu/g x $10^{5}$ in profile $1 ; 3.00-5.90 \mathrm{cfu} / \mathrm{g} \times 10^{5}$ in profile 2 and 6.00$6.70 \mathrm{cfu} / \mathrm{g} \mathrm{x} 10^{5}$ in profile 3 . The bacterial density reduced down the three profiles with the least density in profile 2 . Respiratory rate $(\mathrm{RR})$ ranged from $0.91-2.72$ in profile $1 ; 0.62-3.65$ in profile 2 and $0.37-4.12$ in profile 3.

\subsection{Fifty Seven Years Old Oil Palm Block (B-57)}

The result of soil analysis of the biological properties of B57 is presented in Table 4 . Bacterial density was moderate and ranged from $3.50-4.00 \mathrm{cfu} / \mathrm{g} \times 10^{5}$ in profile $1,5.30-7.90 \mathrm{cfu} / \mathrm{g} \times$ $10^{5}$ in profile 2 and $5.80-6.40 \mathrm{cfu} / \mathrm{g} \times 10^{5}$ in profile 3 . The bacterial density reduced down the three profiles with the least density in profile 1 . Respiratory rate (RR) ranged from $0.58-2.71$ in profile $1 ; 1.24-3.20$ in profile 2 and 1.42-3.13 in profile 3.

The result has shown that the bacteria density decreased down the profile in all the locations. This could be attributed to the fact that the upper horizons contain more materials to be decomposed than the lower horizon, thereby increasing more bacterial activity in the upper horizon. Though there was no significant difference among the blocks, oil palm slightly increased the bacterial density as well as the respiratory rate of the soils of the study area (Table 5). This agrees with the findings of Fairhurst and Hardter (2003) that oil palm improves soil microorganisms processes and activities.

Table 2: Bacterial density and respiratory rate of soils of the 17 years old oil the palm block (B-17)

\begin{tabular}{llll}
\hline Horizon Depth & Horizon Designation & Bac.D $\left(\mathrm{cfu} / \mathrm{g} \times 10^{5}\right)$ & $\mathrm{RR}$ \\
\hline Profile 1 & $\mathrm{Ap}$ & 5.70 & 3.16 \\
$0-20$ & $\mathrm{Bt}_{1}$ & 5.70 & 2.69 \\
$20-40$ & $\mathrm{Bt}_{2}$ & 5.50 & 2.54 \\
$40-70$ & $\mathrm{~B}$ & 5.60 & 2.12 \\
$70-110$ & $\mathrm{BC}$ & 4.30 & 1.99 \\
$110-148$ & $\mathrm{C}$ & 4.80 & 1.07 \\
$148-200$ & & 5.27 & 2.26 \\
Mean & & 5.70 & 3.16 \\
Maximum value & & 4.30 & 1.07 \\
Minimum value & & & \\
Profile 2 & $\mathrm{Ap}_{0-20}$ & 8.10 & 3.06 \\
$20-48$ & $\mathrm{Bt}_{1}$ & 8.10 & 2.78 \\
$48-89$ & $\mathrm{~B}_{1}$ & 7.70 & 2.49 \\
$89-124$ & $\mathrm{Bt}_{2}$ & 7.90 & 2.04 \\
124-160 & $\mathrm{Bt}_{2}$ & 6.30 & 1.52 \\
$160-200$ & $\mathrm{C}_{\text {Mean }}$ & 6.40 & 0.99 \\
Maximum value & & 7.42 & 2.15 \\
Minimum value & & 8.10 & 3.06 \\
Profile 3 & & 6.30 & 0.99 \\
0-29 & & & \\
29-62 & $\mathrm{Ap}$ & 7.50 & 3.30 \\
\end{tabular}

This publication is licensed under Creative Commons Attribution CC BY. 


\begin{tabular}{llll}
$62-92$ & $\mathrm{Bt}_{2}$ & 7.10 & 2.07 \\
$92-122$ & $\mathrm{C}_{1}$ & 7.10 & 1.72 \\
$122-158$ & $\mathrm{C}_{2}$ & 5.80 & 1.52 \\
$158-200$ & $\mathrm{C}_{3}$ & 6.00 & 1.42 \\
Mean & & 6.85 & 2.17 \\
Maximum value & & 7.60 & 3.30 \\
Minimum value & & 5.80 & 1.42 \\
\hline
\end{tabular}

Source: Field data (2017)

Bac. $D=$ bacterial density, $R R=$ respiratory rate, Horizon design-horizon designation

Table 3: Bacterial density and respiratory rate of soils of the 39 years old oil the palm block (B-39)

\begin{tabular}{llll}
\hline Horizon Depth & Horizon Designation & Bac.D (cfu/g x 105) & RR \\
\hline Profile 1 & & & \\
$0-23$ & $\mathrm{Ap}^{5}$ & 6.50 & 2.72. \\
$23-52$ & $\mathrm{Bt}_{1}$ & 6.30 & 2.15 \\
$52-87$ & $\mathrm{~B}$ & 5.50 & 1.85 \\
$87-121$ & $\mathrm{Bt}_{2}$ & 5.40 & 1.56 \\
$121-154$ & $\mathrm{C}_{1}$ & 3.00 & 1.16 \\
$154-200$ & $\mathrm{C}_{2}$ & 3.30 & 0.91 \\
Mean & & 5.00 & 1.73 \\
Maximum value & & 6.50 & 2.72 \\
Minimum value & & 3.00 & 0.91 \\
Profile 2 & & & \\
$0-24$ & $\mathrm{Ap}_{24-55}$ & 5.90 & 3.65 \\
s555-87 & $\mathrm{Bt}_{1}$ & 5.60 & 3.50 \\
$87-120$ & $\mathrm{~B}_{1}$ & 5.10 & 2.96 \\
120-150 & $\mathrm{Bt}_{2}$ & 3.00 & 1.52 \\
150-200 & $\mathrm{C}_{1}$ & 3.60 & 0.79 \\
Mean & $\mathrm{C}_{2}$ & 3.00 & 0.62 \\
Maximum value & & 4.37 & 2.17 \\
Minimum value & & 5.90 & 3.65 \\
Profile 3 & & 3.00 & 0.62 \\
$0-25$ & & & \\
25-54 & & 6.70 & 4.12 \\
$54-79$ & $\mathrm{Ap}_{79-107}$ & 6.50 & 3.76 \\
107-130 & $\mathrm{Bt}_{1}$ & 6.00 & 2.12 \\
130-200 & $\mathrm{Bt}_{2}$ & 6.60 & 1.68 \\
Mean & $\mathrm{Bt}_{3}$ & 6.20 & 1.53 \\
Maximum value & $\mathrm{C}_{1}$ & 6.40 & 0.37 \\
Minimum value & $\mathrm{C}_{2}$ & 6.40 & 2.26 \\
\hline & & 6.70 & 4.12 \\
\hline
\end{tabular}

Source: Field data (2017)

$\mathrm{Bac} . \mathrm{D}=$ bacterial density, $\mathrm{RR}=$ respiratory rate, Horizon design-horizon designation

Table 4: Bacterial density and respiratory rate of soils of the 57 years old oil the palm block (B-57)

\begin{tabular}{llll}
\hline Horizon Depth & Horizon Designation & Bac.D $\left(\mathrm{cfu} / \mathrm{g} \times 10^{5}\right)$ & $\mathrm{RR}$ \\
\hline Profile 1 & & & \\
$0-27$ & $\mathbf{A p}$ & $\mathbf{4 . 0 0}$ & $\mathbf{2 . 7 1}$ \\
$7-50$ & $\mathbf{B t}_{1}$ & $\mathbf{4 . 0 0}$ & $\mathbf{2 . 3 2}$ \\
$50-84$ & $\mathbf{B t}_{2}$ & $\mathbf{3 . 7 0}$ & $\mathbf{1 . 7 9}$ \\
$84-116$ & $\mathbf{C}_{1}$ & $\mathbf{3 . 6 0}$ & $\mathbf{1 . 7 0}$ \\
$116-160$ & $\mathbf{C}_{2}$ & $\mathbf{3 . 5 0}$ & $\mathbf{1 . 2 4}$ \\
$160-200$ & $\mathbf{C}_{3}$ & $\mathbf{3 . 6 0}$ & $\mathbf{0 5 8}$ \\
Mean & & $\mathbf{3 . 7 3}$ & $\mathbf{1 . 7 2}$ \\
Maximum value & & $\mathbf{4 . 0 0}$ & $\mathbf{2 . 7 1}$ \\
\hline
\end{tabular}




\begin{tabular}{llll}
\hline Minimum value & & $\mathbf{3 . 5 0}$ & $\mathbf{0 . 5 8}$ \\
Profile 2 & Ap & $\mathbf{7 . 9 0}$ & $\mathbf{3 . 2 0}$ \\
$0-27$ & $\mathbf{B t}_{1}$ & $\mathbf{7 . 7 0}$ & $\mathbf{2 . 9 0}$ \\
$27-57$ & $\mathbf{B t}_{2}$ & $\mathbf{7 . 5 0}$ & $\mathbf{2 . 6 7}$ \\
$37-90$ & $\mathbf{B t}_{3}$ & $\mathbf{6 . 4 0}$ & $\mathbf{2 . 4 0}$ \\
$90-120$ & $\mathbf{C}_{1}$ & $\mathbf{6 . 1 0}$ & $\mathbf{1 . 5 4}$ \\
$120-155$ & $\mathbf{C}_{2}$ & $\mathbf{5 . 3 0}$ & $\mathbf{1 . 2 4}$ \\
$155-200$ & & $\mathbf{7 . 8 2}$ & $\mathbf{2 . 3 3}$ \\
Mean & & $\mathbf{7 . 9 0}$ & $\mathbf{3 . 2 0}$ \\
Maximum value & & $\mathbf{5 . 3 0}$ & $\mathbf{1 . 2 4}$ \\
Minimum value & & & \\
Profile 3 & Ap & $\mathbf{6 . 1 0}$ & $\mathbf{3 . 1 3}$ \\
$0-29$ & $\mathrm{BA}_{2}$ & $\mathbf{6 . 4 0}$ & $\mathbf{2 . 8 9}$ \\
$29-60$ & $\mathrm{~B}_{1}$ & $\mathbf{6 . 2 0}$ & $\mathbf{2 . 0 7}$ \\
$60-92$ & $\mathbf{B}_{2}$ & $\mathbf{6 . 0 0}$ & $\mathbf{1 . 7 2}$ \\
$92-124$ & $\mathbf{C}_{1}$ & $\mathbf{6 . 0 0}$ & $\mathbf{1 . 5 2}$ \\
$924-160$ & $\mathbf{C}_{2}$ & $\mathbf{5 . 8 0}$ & $\mathbf{1 . 4 2}$ \\
$160-200$ & & $\mathbf{6 . 0 8}$ & $\mathbf{2 . 1 3}$ \\
Mean & & $\mathbf{6 . 4 0}$ & $\mathbf{3 . 1 3}$ \\
Maximum value & & $\mathbf{5 . 8 0}$ & $\mathbf{1 . 4 2}$ \\
Minimum value & &
\end{tabular}

Source: Field data (2017)

Bac. $\mathrm{D}=$ bacterial density, $\mathrm{RR}=$ respiratory rate, Horizon design-horizon designation

Table 5: Comparing means of Bacterial Density and Respiratory Rate in the four blocks: B-0, B-17, B-39 and B-57

\begin{tabular}{lllll}
\hline YEAR & 0 & 17 & 39 & 57 \\
\hline Bd cfu/g x 10 & 4.63 & 4.89 & 4.93 & 3.38 \\
L.SD & 3.81 & & & \\
RR & 2.25 & 2.14 & 2.32 & 2.13 \\
LSD & 0.46 & & & \\
\hline
\end{tabular}

Source: Field data (2017)

$\mathrm{Bd}=$ Bacterial density, $\mathrm{RR}=$ Respiratory rate, $\mathrm{LSD}=$ Least significant different

Bacterial density was higher in 39 years (B-39), followed by the oil palm block of 17 years (B-17), the no oil palm block (B0 ) and then the oil palm block of 57 years (B-57) (Figure 1, Table 5). The trend was as follows: B-39> B-17> B-0> B-57. The high bacterial density at 39 years could be as result of more palm leaves shed on the soil surface at that period, which brought about more litter materials to be decomposed and as a result the increase in microbial activities in the soil. It is seen that microbial activities increased with the age of oil palm up to 39 years, then decreases as palm ages. Rombeke et al. (2006) and Simpson et al. (2012) observed that oil palm improves fauna and their feeding activity which enhances composition and humification. Also Philip (2008), found that trees deepen soil and facilitate microbial activities. The least bacterial density observed in B-57 could be attributed to the low moisture content observed in the block compared to other blocks. This agrees with the findings of Alexandre and Claudjo (1999) and David et al. (2014) that moisture has tremendous influence on microbial activities Bacterial density was within the critical range of $10^{4}-10^{5} \mathrm{cfug}$ described by USDA (2006).

The respiratory rate shows the activities of the microorganisms. The respiration rate of the microorganisms decreased down the profile and followed the same trend as the microbial density. Increase in bacterial density increased the rate of respiration. This was observed in all the blocks of the study area. This shows that the rate of respiration of microorganism is the soil is directly proportional to the density of the microorganism present in the soil. This corresponds with the report of USDANRCS, 1996 that Respiration rate can be used to detect microbial activity. 


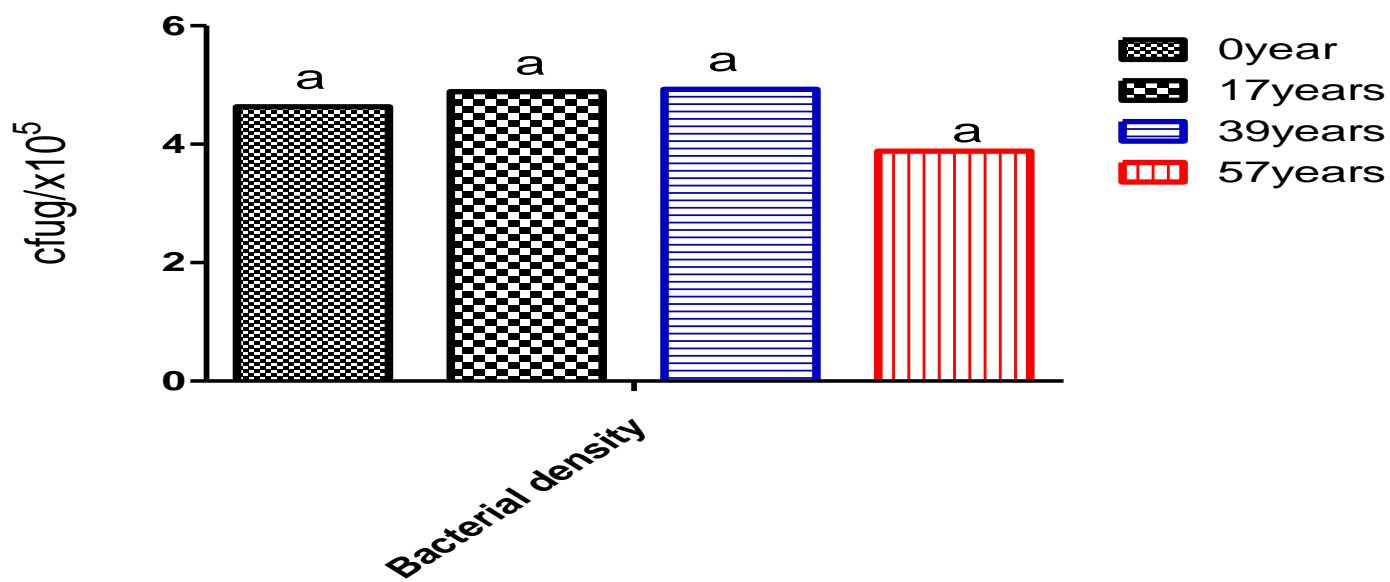

Figure 1: Means of bacterial density among blocks of the study area

3.5 Assessing the variation of microbial activities in the wet and dry season, as influenced by oil palm cultivation

The result of the comparison of the microbial density and respiratory rate for the two seasons, wet and dry season are represented in Table 6 . Bacterial density was significantly higher $(\mathrm{P}<0.05)$ in the wet season than in the dry season in three of the locations; B- 0, B-17 and B -57. This is because moist environment encourages microbial activities. This result agrees with the findings of Lipson et al., 2002., Schadt et al., 2003., Bo Xu et al., 2017, that moisture encourages biological activities.

The bacteria density was the least in wet season in B-39 compared to the other blocks. This could be as a result of the high bulk density of the soil recorded in the block, which may inhibit the free flow of water into the soil thereby reducing the activities of the microorganisms. The respiratory rate followed the same trend as bacterial density. It was higher in the wet season than in the dry season in three of the locations; B-0, B-I7 and B- 57 though not significantly different. Also the respiratory rate in B-39 was lesser in the wet season compared to the dry season. The result also corresponds with the findings of Alexandre and Claudio (1999) and David et al. (2014) that moisture has tremendous influence on microbial activities.

Table 6: Assessing the variation of microbial activities in wet and dry season in the four blocks: B- 0, B-17, B-39 and B-57

\begin{tabular}{lllllllll}
\hline Yrs & $\begin{array}{l}\text { Bd Dry } \\
\text { Cfu/g x 10 }^{\mathbf{5}}\end{array}$ & $\begin{array}{l}\text { Bd wet } \\
\text { cfu/g x 10 }^{\mathbf{5}}\end{array}$ & t-test & $\begin{array}{l}\text { Probability } \\
\text { level }\end{array}$ & $\begin{array}{l}\text { RR } \\
\text { Dry }\end{array}$ & RR Wet & T- test & $\begin{array}{l}\text { Probability } \\
\text { level }\end{array}$ \\
\hline 0 & 4.63 & 6.45 & 4.91 & $<0.01$ & 2.285 & 2.59 & 1.28 & $=0.21$ \\
17 & 4.89 & 6.51 & 2.97 & $<0.005$ & 2.14 & 2.19 & 0.17 & $=0.87$ \\
39 & 4.93 & 5.26 & 6.86 & $=0.39$ & 2.32 & 2.02 & 0.88 & $=0.39$ \\
57 & 3.88 & 5.54 & 3.66 & $<0.001$ & 2.12 & 5.25 & 1.00 & $=0.33$ \\
\hline
\end{tabular}

$\mathrm{Bd}=$ Bacterial Density, RR $=$ Respiration Rate.

\section{CONCLUSION}

The result has shown that oil palm slightly increased the bacterial density as well as the respiratory rate of the soils of the study area. Also the population of the microorganisms reduced down the profile in all the locations, as was also the case in the respiratory rate, which could be contributed to the fact that the upper horizons contain more materials to be decomposed than the lower horizon, thereby increasing more bacterial activity. The study has shown that the respiratory rate of microorganisms and the population of microorganisms in the soil is directly influenced by oil palm cultivation.

\section{REFERENCES}

[1] Abu Bakar R., Darus S.Z., Kulaseharan S. and Jamaluddin, N. (2010). Effects of ten year application of empty fruit bunches in an oil palm plantation on soil chemical properties. Nutrient Cycling in Agroecosystems 89, 341-349.

[2] Alexandre, G. S. and Claudio, A. (1999). The influence of moisture and microbial activity of soils. Thermochimica Acta, 332: 71-174.

[3] Bo, X., Jinniu, W., Ning, W., Yan, W. and Fusun, S. (2017). Seasonal and inter-annual and seasonal dynamics of soil microbial biomass and available nitrogen in an alpine meadow in the eastern part of Qinghai-Tibet plateau, China: Journal Biogeosciences. P-66.

[4] David, J. V., Jordan, G. 0., Heather, N. B., Micheal, N. G., John, E. B. and Cristians D. T. (2014), Soil microbial responses to increased moisture and organic resources along a salinity gradient in a polar desert. America Society for microbiology, 10: 67-89.

[5] Doran, J. W., M. Sarrantonio, and M.A. Liebig, (1996).Soil health and sustainability. P. 1-54. In:D.L. Sparks (ed.) Advances in Agronomy, vol. 56. Academic Press, San Diego, CA.

[6] Fairhurst, T. and Härdter, R. (Editors) (2003). Oil palm management for large and sustainable yields. Potash \& Phosphate Institute/Potash \& Phosphate Institute of Canada and International Potash Institute: Singapore, 63p. 
[7] Foster, W.A., Snaddon J.L., Turner E.C., Fayle T.M., Cockerill T.D., Eliwood M.D.F. et a!. 2011. Establishing the evidence base for maintaining biodiversity and ecosystem function in theoil palm landscapes of South East Asia. Philosophical Transactions of the Royal Society of London, Series B: Biological Sciences, 366: 3277-3291.

[8] Lipson, D. A., Schadt, C.W., and Schmidt, S. K. 2002. Changes in soil microbial community structure and function in an alpine dry meadow following spring snow melt. Microbiology and Ecology, 43, 307-314.

[9] Nester, E. W., Robert C. E., and Nester M. T. 2006. Microbiology human perspective. USA. WMC. Brown Publishers. Pp. 23: 5 14-530.

[10] Pauli, N., Donough, C., OberthUr, T., Cock, J, Verdooren, R., Rahmadsyah, Abdurrohim, G., Indrasuara, K., Lubis, A., Dolong, T. and Pasuquin, J.M. (2014). Changes in soil quality indicators under oil palm plantations following application of 'best management practices' in a four-year field trial. Agriculture, Ecosystems and Environment 195: 98-111.

[11] Philips, J. D. (2008). Soil System modelling and generation of field hypotheses. Geordema, 145(3-4): 419-425.

[12] Rombke, J., Hofer, H., Garcia, M.V. B. and Martius, C. (2006). Computing: Vienna, Austria. Feeding activities of soil organisms at four different forest sites in Central Amazonia using the bait lamina method. Journal of Tropical Ecology, 22: 313-320.

[13] Sahat, S. Yusop, Z. Askari, M. and Ziegler, A. D. 2016. Estimation of soil erosion rates in oil palm plantation with different land cover. Top conference series. Material Science and Engineering. P-36.

[14] Sayer J., Ghazoul J., Nelson P. and Klintuni Boedhihartono A. (2012). Oil palm expansion transforms tropical landscapes and livelihoods. Global Food Security 1: 114-19.

[15] SPSS 18.0 (2011) Microsoft windows. Statistical Package for Social Sciences. SPSS mc, Chicago, $6 \mathrm{p}$.

[16] Udoh, B. T. (2003). An Evaluation of the Soil Map of Akwa Ibom State for Agricultural Land Use. MSc (Ed) Dissertation. University of Ibadan, Nigeria, 13Op.

[17] Ukwuteno, S. O., Okoroji, E. C. and Opaluwa, H. I. (2012). Determination of economic optimum replacement of age of oil palm in kogi state, Nigeria. International Journal of Applied Research and Technology, 1(2): 68-76.
[18] USDA (United State Department of Agriculture) (2006). Indicators for Soil Quality Evaluation (Soil Quality Information Sheet). USDA, Washington 137p.

[19] USDA-FAS, 2014. Oilseeds: World markets and trade. Circular Series.US Department of Agriculture - Foreign Agricultural Service, Washington DC.

[20] Verheye, W. (2010). Growth and production of oil palm, pp6-10. In: W. Verheye (Editor) Land Use, Land Cover and Soil Sciences. Encyclopedia of life support systems (EOLSS), UNESCO-EOLSS Publishers, Oxford, UK, $56 \mathrm{p}$.

\section{AUTHORS}

First Author - Chukwu, E. D, Department of Soil Science and Technology, Federal University of Technology P.M. B. 1526

Owerri, Imo State, Nigeria.

Second Author - Udoh, B. T, Department of Soil Science and Land Resources Management, University of Uyo, Uyo, P.M.B 1017 Akwa Ibom State, Nigeria

Third Author - Okoli, N. H, Department of Soil Science and Technology, Federal University of Technology P.M. B. 1526 Owerri, Imo State, Nigeria.

Fourth Author - Nnabuihe, E. C, Nnamdi Azikiwe University,P.M.B. 5025 Awka, Anambra State, Nigeria

Corresponding author's Email: ebelechukwu5@gmail.com 08037972641, Postal Address: 39 Apostolic road Edem Akai Uyo, Akwa Ibom State, Nigeria. Postal code:520231 